\title{
Brazilian Peppertree Thrips Pseudophilothrips ichini (Hood) (Insecta: Thysanoptera: Phlaeothripidae) ${ }^{1}$
}

\author{
Patricia Prade, Carey R. Minteer, and James P. Cuda ${ }^{2}$
}

\section{Introduction}

The Brazilian peppertree thrips, Pseudophilothrips ichini (Hood) (Thysanoptera: Phlaeothripidae), is an insect native to Brazil (Figure 1). This species has been studied for the last 20+ years as a potential biological control agent of Brazilian peppertree, Schinus terebinthifolia Raddi (Sapindales: Anacardiaceae), in Florida (Cuda et al. 2008; Cuda et al. 2008; Manrique at al. 2014; Wheeler et al. 2016a, b). Host specificity experiments demonstrated that Pseudophilothrips ichini has a limited host range (Cuda et al. 2008; Cuda et al. 2009; Wheeler et al. 2017) and can cause a severe reduction of Brazilian peppertree biomass (Manrique at al. 2014).

\section{Distribution}

Pseudophilothrips ichini currently is concentrated in eastern Brazil, overlapping some of the areas of distribution of Brazilian peppertree as documented by Wheeler et al. (2016b, 2017) (Figure 2). As of spring 2019, Pseudophilothrips ichini has not yet been released into the United States, but release permits are pending for Florida.

Using data from cold-tolerance experiments, Manrique et al. (2014) predicted that Pseudophilothrips ichini can potentially establish in the southeastern United States, Arizona, California, and Texas, overlapping some of the areas where Brazilian peppertree is present (Figure 3).

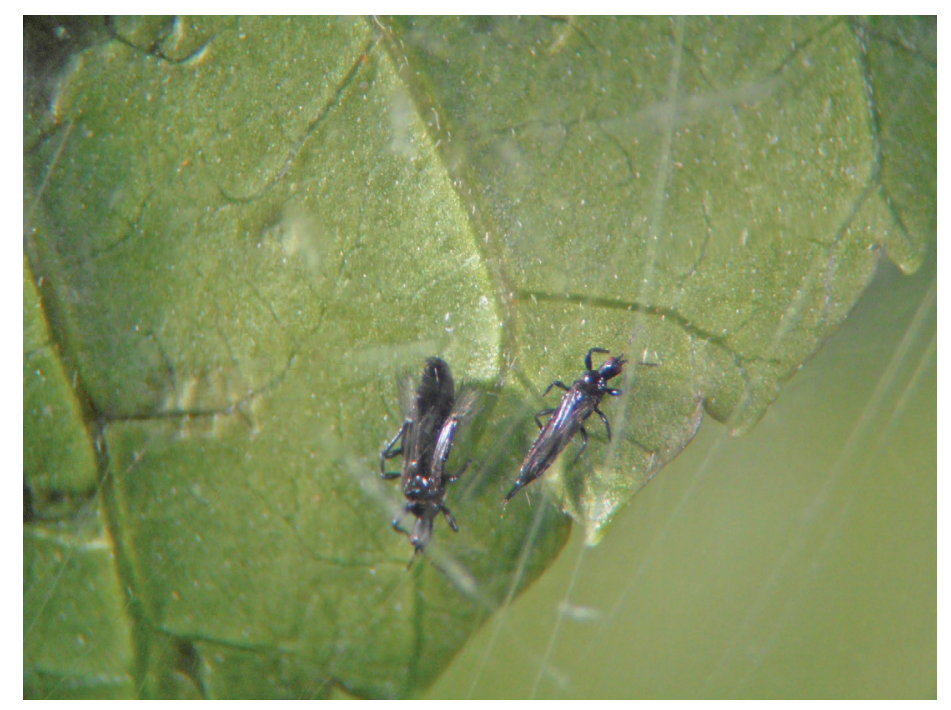

Figure 1. Pseudophilothrips ichini Hood adults on Schinus terebinthifolia Raddi.

Credits: Carey R. Minteer, UF/IFAS

\section{Description}

\section{Eggs}

Pseudophilothrips ichini adults lay eggs on leaflet blades and pedicels of new growth tissues of Brazilian peppertree. Eggs are 0.02 inches $(0.4 \mathrm{~mm})$ in length, ovoid, and golden in color (Figure 4) (Cuda et al. 2008).

1. This document is EENY-737, one of a series of the Entomology and Nematology Department, UF/IFAS Extension. Original publication date July 2019. Visit the EDIS website at https://edis.ifas.ufl.edu for the currently supported version of this publication. This document is also available on the Featured Creatures website at http://entomology.ifas.ufl.edu/creatures.

2. Patricia Prade, Entomology and Nematology Department, UF/IFAS Indian River Research and Education Center; Carey R. Minteer, IRREC; and James P. Cuda, professor, Entomology and Nematology Department; UF/IFAS Extension, Gainesville, FL 32611.

The Institute of Food and Agricultural Sciences (IFAS) is an Equal Opportunity Institution authorized to provide research, educational information and other services

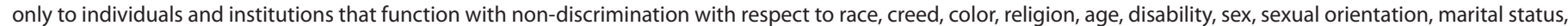

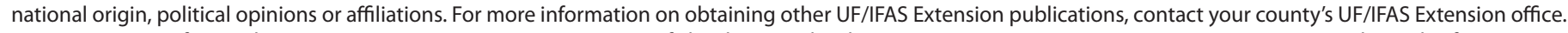
U.S. Department of Agriculture, UF/IFAS Extension Service, University of Florida, IFAS, Florida A \& M University Cooperative Extension Program, and Boards of County Commissioners Cooperating. Nick T. Place, dean for UF/IFAS Extension. 


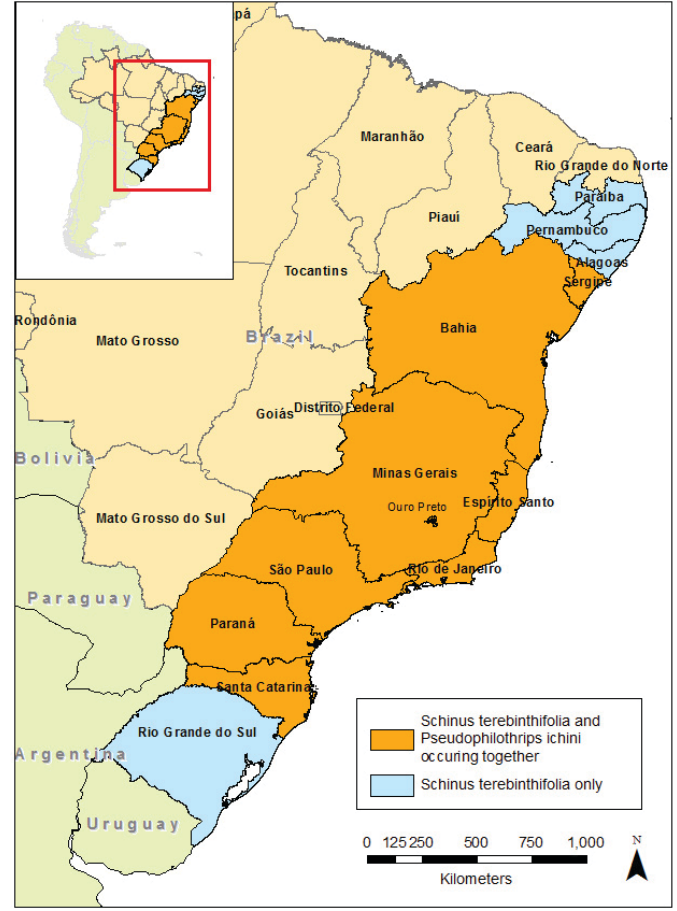

Figure 2. Distribution of Pseudophilothrips ichini Hood and its primary host plant Schinus terebinthifolia Raddi in Brazil.

Credits: Produced by Lyndall C. Brezina, adapted from Wheeler et al. (2016b), University of Florida, Gainesville, FL

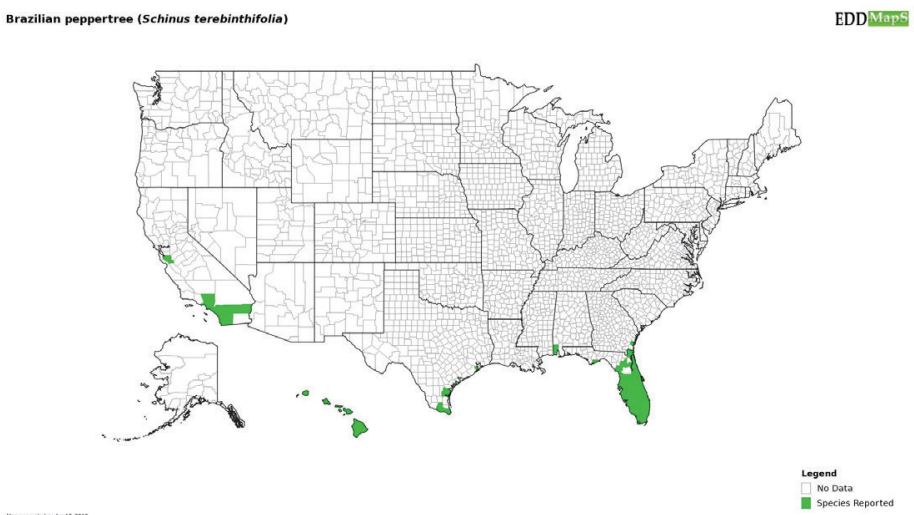

Figure 3. Schinus terebinthifolia Raddi distribution in North America. Credits: Center for Invasive Species and Ecosystem Health, EDDMaps, University of Georgia, GA

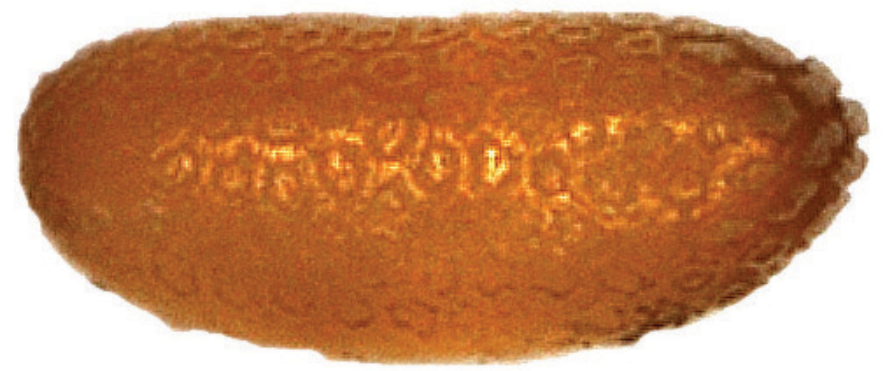

Figure 4. Egg of Pseudophilothrips ichini Hood.

Credits: Nick Silverson, USDA-ARS

\section{Larvae}

Pseudophilothrips ichini has two larval instars. The first larval instar is yellow or light orange in color and is 0.03 inches $(0.7 \mathrm{~mm})$ in length (Figure $5 \mathrm{~A})$. The second larval instar is similar in color to the first larval instar but is 0.04 inches $(1.0 \mathrm{~mm})$ in length (Figure $5 \mathrm{~B})$. Besides body size, the second larval instar can be differentiated from the first by the presence of two horizontal lines on the last few segments of the body (Cuda et al. 2008; Wheeler et al. 2016b).

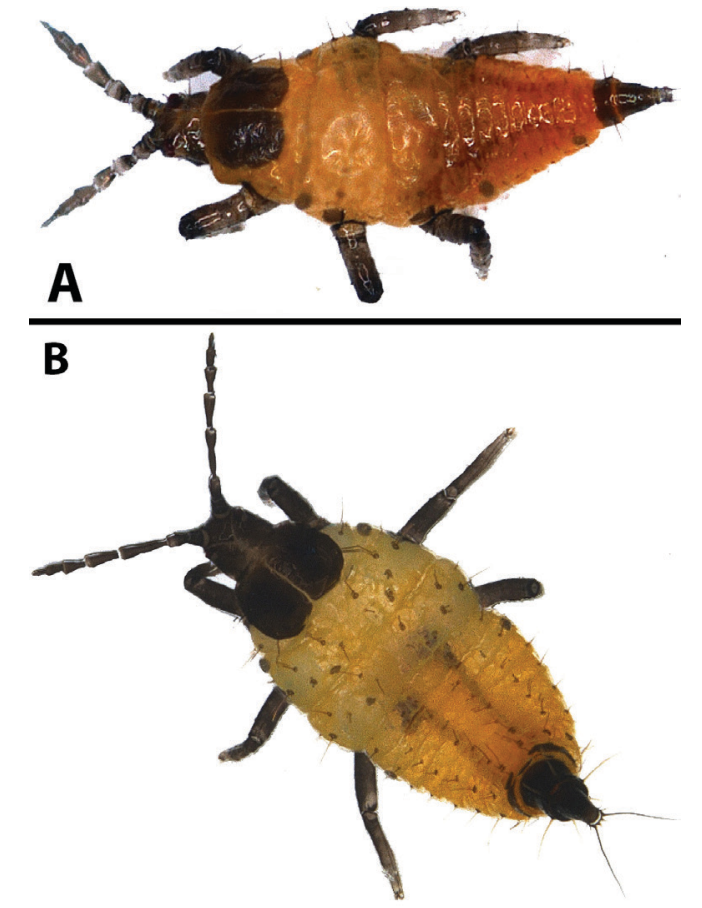

Figure 5. Larvae of Pseudophilothrips ichini Hood. A: first larval stage and B: second larval stage.

Credits: Nick Silverson, USDA-ARS

\section{Pupae}

There are three pupal instars. The first stage, called the pre-pupal instar, is 0.6 inches $(1.6 \mathrm{~mm})$ in length, has short antennae, and lacks wing buds (Figure 6A). The next stage, called the first pupal instar, is 0.07 inches $(1.9 \mathrm{~mm})$ in length and has small wing buds (Figure 6B). The final instar, referred to as the second pupal stage, is 0.8 inches $(2.1 \mathrm{~mm})$ in length, has longer antennae, and has wing buds (Figure 6C) (Wheeler et al. 2016b).

\section{Adults}

Adults are winged, small ( 0.08 to 0.12 inches) (2 to 3 $\mathrm{mm}$ ), black, and sexually dimorphic (Figure 7). Sexually dimorphic in this particular species means the adult males are relatively smaller than females (Cuda et al. 2009). 

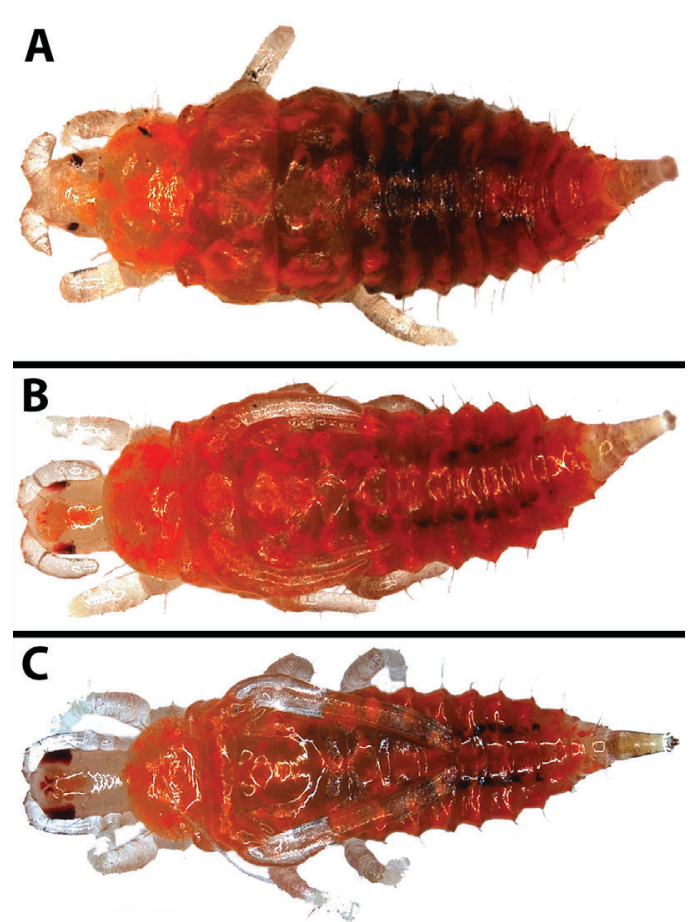

Figure 6. Pupal instars of Pseudophilothrips ichini Hood. A: pre-pupal stage, B: first pupal stage, and C: second pupal stage.

Credits: Nick Silverson, USDA-ARS

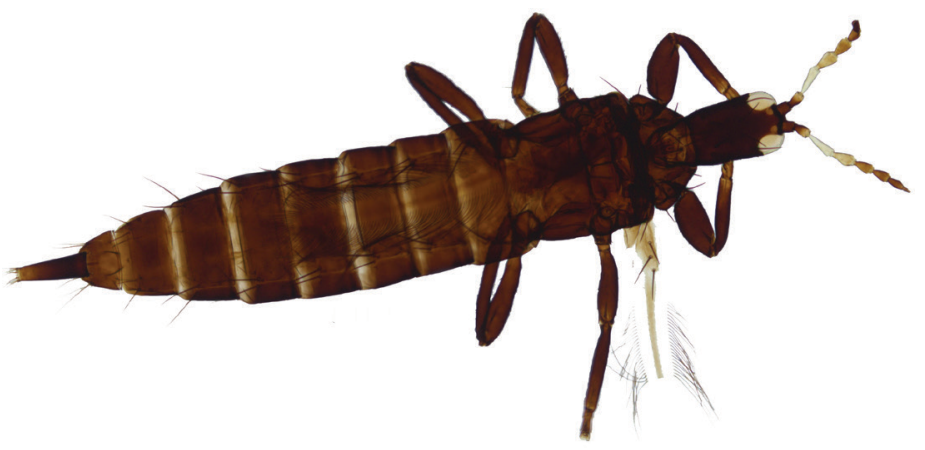

Figure 7. Pseudophilothrips ichini Hood adult.

Credits: Nick Silverson, USDA-ARS

\section{Life Cycle}

Reproduction can be sexual or by arrhenotoky, which is the production of females from fertilized eggs and males from unfertilized eggs (Bowen and Stern 1966; Cuda et al. 1999; Cuda et al. 2008; Wheeler et al. 2016b). Developmental time from egg to adult ranges from 18 to 34 days and is temperature dependent. Adults and larvae use their rasping-sucking mouthparts to make and feed on ruptures in the cells of Brazilian peppertree; pupation occurs in the soil, and all pupae stages do not feed. Adults lay eggs on new growth, and after 5 to 8 days, the larvae hatch. Larval stage lasts for 8 to 12 days, and pupal stage for 5 to 14 days (Manrique et al. 2014).

\section{Hosts}

Schinus terebinthifolia, the primary host of Pseudophilothrips ichini, is a perennial shrub native to Argentina, Brazil, Paraguay, and Uruguay (Barkley 1944) (Figure 8). Introduced into Florida in the mid-1800s, Brazilian peppertree is considered one of the most aggressive invasive weed species in Florida (Morton 1978; Schmitz et al. 1997; Cuda et al. 1999; Cuda et al. 2006; Manrique et al. 2013). Native range observations and host-range tests show that Pseudophilothrips ichini is highly specific to Brazilian peppertree (Cuda et al. 1999; Cuda et al. 2009; Wheeler et al. 2016b).

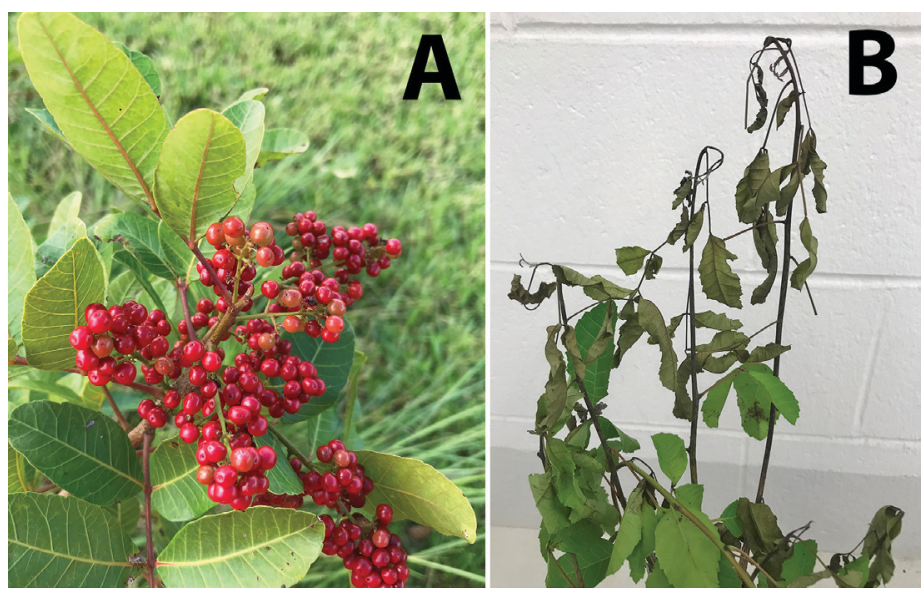

Figure 8. Schinus terebinthifolia Raddi plants. A: Plant with fruits, B: Plant damaged by Pseudophilothrips ichini Hood.

Credits: Patricia Prade, UF/IFAS

Wheeler et al. (2017) found that during no-choice host specificity experiments, Pseudophilothrips ichini was able to complete development and produce offspring on Brazilian peppertree (target species) and 10 other species (non-target species). Reproduction and survival on non-target species were reduced compared to reproduction and survival on Brazilian peppertree. The average number of adults produced on Brazilian peppertree was 124. However, 20.3 adults on average were produced from Peruvian peppertree, Schinus molle L. (Sapindales: Anacardiaceae), a non-native invasive ornamental in California, and on average, 1.8 adults were produced on each of the other nine species tested. When given a choice between Brazilian peppertree and non-target species, Pseudophilothrips ichini was able to produce adult offspring on only four non-target species (Schinus molle L., Pistacia vera L., Rhus glabra L., and Rhus sandwicensis A. Gray). However, the number of adult offspring produced on Brazilian peppertree was on average 71 , much higher than on non-target species that had an average of 0.9 adult offspring produced (Wheeler et al. 2017). 


\section{Economic Importance}

Feeding by Pseudophilothrips ichini reduces Brazilian peppertree growth, reduces plant height, reduces the number of green stems produced, and causes flower abortion. More importantly, plants attacked by Pseudophilothrips ichini are slow to recover and less vigorous, with a reduction in the number of leaves and green stems, plant height, and growth rate, as well as limited fruit production when compared with non-attacked plants (Cuda et al. 1999; Manrique et al. 2014).

Brazilian peppertree management costs are high. In fiscal year 2015-2016, the South Florida Water Management District spent \$2.6 million to control Brazilian peppertree (Cuda et al. 2017; Rodgers et al. 2017). Pseudophilothrips ichini was recommended for release by the United States Department of Agriculture - Technical Advisory Group in 2016 (Cuda et al. 2016). When the biological control program for Brazilian peppertree is implemented, Pseudophilothrips ichini is expected to reduce the impact of Brazilian peppertree on the environment and potentially reduce the need for other control techniques.

\section{References}

Barkley FA. 1944. “Schinus L.” Brittonia 5: 160-198.

Bowen WR, Stern VM. 1966. "Effect of temperature on the production of males and sexual mosaics in a uniparental race of Trichogramma semifumatum (Hymenoptera: Trichogrammatidae)." Annals of the Entomological Society of America 59: 823-834.

Cuda JP, Habeck DH, Overholt WA, Medal JC, PedrosaMacedo JH, Vitorino MD. 1999. Classical Biological Control of Brazilian Peppertree (Schinus terebinthifolia) in Florida. ENY-820. Gainesville: University of Florida Institute of Food and Agricultural Sciences. http://edis.ifas.ufl.edu/ in114 (24 April 2018)

Cuda JP, Ferriter AP, Manrique V, Medal JC. 2006. “Florida’s Brazilian peppertree management plan." Recommendations from the Brazilian peppertree task force Florida Exotic Pest Plant Council, pp. 1-82, 2nd ed., Florida Exotic Pest Plant Council, Gainesville, FL.

Cuda JP, Gillmore JL, Medal JC, Pedrosa-Macedo JH. 2008. "Mass rearing of Pseudophilothrips ichini (Thysanoptera: Phlaeothripidae), an approved biological control agent for Brazilian peppertree, Schinus terebinthifolius (Sapindales: Anacardiaceae)." Florida Entomologist 91: 338-40.
Cuda JP, Medal JC, Gillmore J, Habeck D, Pedrosa-Macedo JH. 2009. "Fundamental host range of Pseudophilothnps ichini sl. (Thysanoptera: Phlaeothripidae): A candidate biological control agent of Schinus terebinthifolius (Sapindales: Anacardiaceae) in the United States." Environmental Entomology 38: 1642-1652.

Cuda JP, Prade P, Minteer CR. 2017. Yellow Brazilian Peppertree Leaf-Galler. EENY-689. Gainesville: University of Florida Institute of Food and Agricultural Sciences. http:// edis.ifas.ufl.edu/in1186 (13 April 2018)

Manrique V, Cuda JP, Overholt WA. 2013. Brazilian peppertree: A poster child for invasive plants in Florida. Journal of Florida Studies 1(2). http://www.journaloffloridastudies. org/0102peppertree.html (10 April 2018)

Manrique V, Diaz R, Erazo L, Reddi N, Wheeler GS, Williams D, Overholt WA. 2014. "Comparison of two populations of Pseudophilothrips ichini (Thysanoptera: Phlaeothripidae) as candidates for biological control of the invasive weed Schinus terebinthifolia (Sapindales: Anacardiaceae)." Biocontrol Science and Technology 24: 518-535.

Morton JF. 1978. "Brazilian pepper: Its impact on people, animals and the environment." Economic Botany 32: 353-359.

Rodgers L, Mason C, Bodle M, Brown R, Ellen A, Tipping P, Rochford M, Mazzotti F, Peters A, Renda M, Beeler C, Ketterlin-Eckles J, Laroche F, Segura C, Serbesoff-King K. 2017. Chapter 7: Status of nonindigenous species, pp. 1-58, in 2017 South Florida Environmental Report, Vol. I. The South Florida Environment. South Florida Water Management District, West Palm Beach, FL.

Schmitz DC, Simberloff D, Hofstetter RH, Haller W, Sutton D. 1997. The Ecological Impact of Nonindigenous Plants. In Simberloff D, Schmitz DC, Brown TC, eds. Strangers in paradise: Impact and management of nonindigenous species in Florida, pp. 39-61. Washington, DC: Island Press.

Wheeler GS, McKay F, Vitorino MD, Manrique V, Diaz R, Overholt WA. 2016a. "Biological control of the invasive weed Schinus terebinthifolia (Brazilian Peppertree): A review of the project with an update on the proposed agents." Southeastern Naturalist 15: 15-34. 
Wheeler GS, Silverson N, Dyer K, Mc Kay F. 2016b.

"Brazilian collections and laboratory biology of the thrips Pseudophilothrips ichini (Thysanoptera: Phlaeothripidae): a potential biological control agent of the invasive weed Brazilian peppertree (Sapindales: Anacardiaceae)." Florida Entomologist 99: 6-11.

Wheeler GS, Manrique V, Overholt WA, Mc Kay F, Dyer K. 2017. "Quarantine host range testing of Pseudophilothrips ichini, a potential biological control agent of Brazilian peppertree (Schinus terebinthifolia) in North America and Hawaii." Entomologia Experimentalis et Applicata 162: 204-217. 